\title{
Monika Górska-Olesińska
}

University of Opole

Institute of Polish and Cultural Studies

\section{LITERARY PRACTICES AND PERFORMANCES IN TRANSMEDIA ENVIRONMENTS: INTRODUCTION TO THE SPECIAL ISSUE}

The semantic capacity of the terms transmedia and transmediality, their openness and ambiguity, makes these useful and operational tools for describing the dynamic reconfiguration of the field of contemporary art. The term "transmedia", which appears in the title of this special issue of Cultural Studies Review, is used in a broad sense. Firstly, it refers to the discourse of convergence culture, capturing the dynamics of the intermingling of technologies, distribution platforms, communication and creative strategies, audience behaviours and production models. Secondly, the term designates diverse artistic practices that go beyond the boundaries of the specific medium. With reference to the elaborations of the authors of Themes of Contemporary Art: Visual Art after 1980, Ryszard Kluszczyński has the following to say:

\begin{abstract}
Art nowadays abandons the need to aim at structural and material unity [...], as it no longer fits into its present form within the traditionally laid limits marked by the parameters of the chosen type and medium. In the frame drawn in this way [...], neither the purity of the genre, nor the features nourished and explored in the artistic activities that are characteristic for the used media, defines the works created nowadays. On the contrary, the various transgressive features and hybridity shaped by it are among the dominant attributes of modernity that reach the rank of representative ones [...] The experience suggested by modern art becomes more and more frequently and importantly a conversation with heterogenic structures, varied inside and on the level of structure or material. Transmediality defines the latest character of artistic practices. ${ }^{1}$
\end{abstract}

The adoption of a transmedia perspective does not, however, mean that we must remove reflections on media specificity from our discussion of modern-day artistic practices. On the contrary, researchers concerned with the transmedia phenomenon are eager to use the tools of media-specific analysis. Such tools are employed to accurately describe the complex narratives presented across multiple media platforms and formats. But also, and above all, these tools capture the specificities of the com-

R.W. Kluszczyński, "Nomadic Images: Transmediality and Hybridity in Contemporary Media Art", Art Inquiry 2011, no. 15, p. 119-133. 
plex processes by which art and media participate in one another, in which individual media "constantly engage in a recursive dynamic of imitating each other, incorporating aspects of competing media into themselves while simultaneously flaunting the advantages of their own forms of mediation offer." ${ }^{2}$ As the editors of the volume Transmedia Frictions: The Digital, the Arts, and the Humanities, Marsha Kinder and Tara McPherson, emphasize:

Paradoxically, even within our current era of postmedia pronouncements, one of the most vibrant transmedia frictions is the debate over medium specificity [...]. Given the increasingly rapid emergence and convergence of new media forms, it is possible to argue, that a discourse on medium specificity enables us to explore the social and aesthetic potential of each and thereby recuperate unique possibilities that otherwise might be lost. As N. Katherine Hayles puts it most succinctly, precisely because of the accelerating speed of these combinations, "clarity about the functionalities of different media is now more crucial that ever". Or to state it another way, transmedia networks share the similar dynamics with transnational studies; movement beyond the boundaries of any specific medium or nation does not render those entities or their borders meaningless, but rather requires us to look more closely at the cultural and historical specificity of the particular combination. ${ }^{3}$

Agnieszka Przybyszewska's essay, which opens this volume, demonstrates an awareness of transmedia tensions, the frictions that exist between old and new literary forms. Przybyszewska examines the discourse surrounding the most recent studies of modern interface-oriented literature. She does so by entering into dialogue with various concepts of textual materialism; among others, texts by Johanna Drucker, N. Katherine Hayles and Jessica Pressmann. She enriches the concept of textual materialism with original concepts: "shiftbooks" and "shiftliterature" are both terms that were created via an analogy with Antoni Porczak's concept of "shiftart". As the author argues,

[Porczak's] catchy metaphor of "shift" escapes tricky distinctions in terminology such as the one between a "medium" and an "interface" [...] Instead, it cleverly and vividly encompasses what all theories mentioned in this paper have in common, focusing on the communicative and semantic role of the book seen as a technology of literary communication. ${ }^{4}$

The researcher applies the term "shiftbook" across media, including print and digital literary texts. She proves the usefulness of her concept via a thorough analysis of the works of Milorad Pavić, author of the Dictionary of the Khazars (1984). In her analysis, Przybyszewska includes non-linear stories enclosed in a codex form, but

2 See: N.K. Hayles, "Print Is Flat, Code Is Deep: The Importance of Media-Specific Analysis", in: M. Kinder, T. McPherson (eds.), Transmedia Frictions: The Digital, the Arts, and the Humanities, Oakland, CA: University of California Press, 2014, p. 21.

3 M. Kinder, T. McPherson, "Preface: Origins, Agents, and Alternative Archaeologies", in: eadem (eds.), Transmedia Frictions..., op. cit., p. XVI.

4 A. Przybyszewska, From "Shiftbooks" to "Shiftliterature": Categories of Literary Interfaces and Liberacy in Characterizing Literature of Transmedial Times [in this issue]. 
she also refers to digital editions. This in turn contributes to an interesting discussion about the transfer or displacement of a literary work, the consequences and opportunities involved in shifting from one technology to another, from the domain of wellknown materiality into the domain of new materiality.

The transmedia category is a powerful tool for analysing both current and historical artistic practices. ${ }^{5}$ Therefore, transmedia discourses often initiate a specific archaeology of creative strategies in which media are entangled. ${ }^{6}$ Piotr Marecki's paper is concerned with works that act as precursors to modern experimental spatial writing. Marecki references texts situated at the crossroads of the visual arts and literature: Between (1977) and Nylon Threads (2002) by the prominent Polish concrete poet Stanislaw Dróżdż, and the 1997 installation A Brief History of Chance by Małgorzata Dawidek Gryglicka. These works are viewed as examples of analogue textual caves, anticipating the literary experiments currently taking place within the Cave Automatic Virtual Environment. By properly orchestrating selected case studies, the author shows the gradual transformation of the writing space that has taken place under the conditions imposed by the institution of the art gallery. This ranges from the analogue hypertext of $A$ Brief History of Chance-wherein nodes or lexias were presented on the walls of an exhibition room to form a hypertext that invites a kinetic reading from the audience. ${ }^{7}$ At the other end, we have the network of the Nylon Threads that tightly filled the white cube of the gallery space, becoming an abstract remediation of networked textuality.

Anne Karhio, the next author in this volume, discusses an embodied narrative experience constructed in three-dimensional space - the immersive CAVE2 ${ }^{\mathrm{TM}}$ environment. ${ }^{8}$ Her text is a close-reading of a project by Roderick Coover and Scott Rettberg that was awarded the prestigious Robert Coover Award for a Work of Electronic Literature: Hearts and Minds: The Interrogations Project. ${ }^{9}$ The interactive Virtual Reality performance of Hearts and Minds makes use of the actual testimonies of American soldiers who became torturers, or who directly witnessed acts of violence or interrogation procedures that violated human rights. Audience members are placed in uncomfortable proximity to these disturbing true stories, which have been submitted to the process of "aestheticization", when they enter the immersive, media-rich visualization environment of CAVE2. The contradictory sets of emotions that are

See: T. Załuski, “Transmedialność?”, in: idem (ed.), Sztuki w przestrzeni transmedialnej, Łódź: Akademia Sztuk Pięknych im. Władysława Strzemińskiego w Łodzi, 2010, p. 17.

6 M. Składanek, "Transmedialność i postmedialność - dialektyka konwergencji i dywergencji w nowych mediach", in: T. Załuski (ed.), Sztuki w przestrzeni..., op. cit., p. 77.

7 As with the strings of Ariadne's thread, the reader is lead from one segment of the story to another in a manner that resembles finding one's way out of a labyrinth.

8 CAVE2 ${ }^{\mathrm{TM}}$ is large-scale virtual-reality 320 -degree panoramic environment which provides users with the ability to see 3D stereoscopic content in a near seamless flat LCD technology at 37 Megapixels in 3D resolution. It is located in Electronic Visualization Lab (EVL) at the University of Illinois Chicago (UIC).

9 See: http://www.crchange.net/hearts-and-minds/. 
aroused forces viewers to critically rethink their own relations with discourses of military power. In the spirit of media archaeology, Karhio positions the award-winning project within a history of immersive VR technology that links back to panorama paintings of the eighteenth and nineteenth centuries. At the same time, she questions the claim that VR technology functions as an ultimate empathy machine.

Elsewhere in the volume, Stephanie Strickland and Ian Hatcher reflect upon Strickland's multi-part poem Vniverse, a work that is an embodiment or personification of the idea of the transmedia. At present the Vniverse includes six components: the 2002 Penguin "double book" V:WaveSon.nets/Loosing L'una, which is bound in a tête-bêche format; V:Vniverse, an Adobe Director/Shockwave project created with Cynthia Lawson; the Flash hypermedia poem Errand Upon Which We Came created with M.D. Coverley; a 2014 variant edition of the printed book from SpringGun Press, in which the component Son.nets became Tercets (V:WaveTercets/Loosing L'una); and, lastly, a new Vniverse iPad app, developed with Ian Hatcher partly in order to preserve (or "resuscitate") the digital Vniverse in light of the demise of Shockwave. The proper meaning of the $V$ project is located in both its individual components and its "inbetweenness"; it emerges as the reader moves between the rhetoric of print and the affordances of cyberdiscursive technological interfaces. In the words of Stephanie Strickland:

While six parts, approachable in any order, give rise to a large number of combinatory modes, the actual state of affairs with the $V$ project has stayed constant-it only ever existed partially on any one platform; it has always posed the problem/choice for the reader of not only which platform to read it on initially but also how to read it on that platform; it always exists most intensely in the space between platforms, or media, as one becomes aware of completely different aspects as silent. ${ }^{10}$

Strickland and Hatcher bring out the details of the process of translating Vniverse from Macromedia Flash to an iPad environment. They perform a kind of Platform-Specific Analysis, showing a direct correlation between the interface type/paradigm of interaction and the meanings constructed in the process of embodied reading. Their conclusion puts forward provocative questions: "Can we criticise media from within by doing something like modding? Can we significantly vary pacing or gesture - perhaps especially introducing variability into gestures by creating a family or swarm of works?". It is worth remembering that the preservation strategies associated with migrating electronic literature ${ }^{11}$ and "restoring to life" old e-literary works are part of a broader set of activities and initiatives undertaken to preserve digital heritage. In a way, such strategies simultaneously contribute to the generation of the transmedia condition.

10 S. Strickland, The Death and Re-distribution of " $V$ ". Manuscript submitted for the book \#WomenTechLit ed. by Maria Mencia. Courtesy of author.

11 S. Strickland, I. Hatcher, Loos of Hover: Recreating Shockwave "Vniverse" as an App for iPad [in this volume]. 
Strickland and Hatcher devote their text to the transmedial poem. Another author who contributes to this volume, Tomasz Żaglewski, deals with issues of transmedia storytelling. Żaglewski looks to the three basic tendencies that have shaped definitions of the transmedia - the cognitive, economic and narrative-based research models originated by Jan-Noël Thon, Henry Jenkins and Marie-Laure Ryan respectively - and uses these tendencies as a platform to launch his own definition: "[t]ransmediality is a culturally and socially organized act of reading and understanding a specific type of 'crossing' narration." 12 Through the prism of this definition, the author see the comic book as a special form of (trans)medium, something that is exemplified by a comic book crossover storyline published by DC Comics in mid2012, Night of the Owls.

In the book Uncreative Writing: Managing Language in the Digital Age, Kenneth Goldsmith suggests that in order to regain avant-garde flair, literature should catch up with the visual arts. The reflections of the next author, Ewa Wójtowicz, are centred around the activities of creators who consistently integrate narrative literature into the field of the visual and performance arts. As a case study, Wójtowicz recalls the large-scale performance art of Swedish duo Goldin+Senneby. Headless by Simon Goldin and Jakob Senneby is a narrative, collaborative and self-referential project that includes many elements: an exhilarating murder-mystery written by a fictional writer with the initials K.D., a blog, art installations, a docu-fictional movie, and an academic analysis (the duo is in permanent collaboration with University of Leicester Professor Angus Cameron, who, as spokesman of the project, presents and analyses it at various academic conferences). Developed over the course of a few years, Headless creates a complex space for an ongoing dialogue between the real and fake (or artificial) actors and agents who have created its universe: writers, artists, journalists, academics, bloggers, and designers. Wójtowicz finds that Goldin+Senneby's project reflects the concept of the postmedia, and she instigates an important discussion about new tendencies in artworks that introduce a post-human and posthumanist perspective into the creative sphere.

The problems gestured towards by Wójtowicz when she talks about involving post-human actors in the process of text production are elaborated by Ewelina Twardoch-Raś. Twardoch-Raś performs an extremely interesting and insightful analysis of selected works that emerge at the intersection between the realm of the literary and the realm of "bioart". The works in question represent important reference points on the contemporary map of hybrid artistic practices, defined by Ryszard Kluszczyński using the term "art@science." ${ }^{\prime 3}$ The theorectical framework underpinning the analysis of "biotextuality", in which non-human actors and inside-body actors (author's

12 T. Żaglewski, "Night of the Owls": Defining Transmediality as an Analytical Tool for Reconstructing Comic Book Mythology [in this volume].

13 R.W. Kluszczyński, “Art@Science. About Relations between Art and Science”, in: idem (ed.), Towards the Third Culture: The Co-Existence of Art, Science and Technology, Gdańsk: Centrum Sztuki Współczesnej “Laźnia”, 2013, p. 33. 
term) take part in the creation of (trans)literature, is informed by theories of "affectiveness". Examples include Eduardo Kac's biopoetry project, Diane Gromala's biomorphic font project, and Christian Bök's radical experiment, which resulted in a biomedical cryptogram or "Xenotext". Twardoch-Raś's paper does on the one hand show how e-literary projects cross into experimental research in other disciplines. On the other hand, it contributes in interesting ways to the lively debate about the nature of representation and the role of affect, emotions and experiences of the body in creating various materialities of transmedia projects.

The last article in this volume-Urszula Pawlicka's provocative Essay on Electronic Literature as Platform - is an attempt to look anew at electronic literature. For Pawlicka, electronic literature is not a coherent field of e-literary practices. Rather this category encapsulates a diverse set of platform experiments with literary potential. The volume closes with Piotr Marecki in conversation with Professor Lori Emerson, the founder and director of one of the world's largest humanities laboratories-Media Archaeology Lab (MAL), which is supported by the College of Media, Communication and Information and the Department of English at the University of Colorado at Boulder. Among other themes, the conversation oscillates around the history of platforms; also touches on the possibility of studies that focus on the platform more broadly.

The articles presented in this volume of Cultural Studies Review are the work of literary scholars, media studies experts, aestheticians, art theorists and artists. These researchers point readers towards modes of artistic expression that can be most accurately captured or described using terms with the prefix "trans": transmediality, translatability, transitivity, transculturality. I hope that the texts presented here will be of interest to representatives from various disciplines, as well as members of the Electronic Literature Organization and representatives of the Digital Humanities. To that end, this special issue of Cultural Studies Review offers both thematic and methodological diversity.

Here I would like to express my deep gratitude to the authors and other people involved in the creation of this volume. I believe that the articles collected here will inspire intriguing debates and discussions in the future.

\section{Bibliography}

Goldsmith K., Uncreative Writing: Managing Language in the Digital Age, New York: Columbia University Press, 2011.

Hayles N.K., "Print Is Flat, Code Is Deep: The Importance of Media-Specific Analysis", in: M. Kinder, T. McPherson (eds.), Transmedia Frictions: The Digital, the Arts, and the Humanities, Oakland, CA: University of California Press, 2014.

Kinder M., McPherson T., "Preface: Origins, Agents, and Alternative Archaeologies", in: iidem (eds.), Transmedia Frictions: The Digital, the Arts, and the Humanities, Oakland, CA: University of California Press, 2014. 
Kluszczynski R.W., “Art@Science. About Relations between Art and Science”, in: idem (ed.), Towards the Third Culture: The Co-Existence of Art, Science and Technology, Gdańsk: Centrum Sztuki Współczesnej “Łaźnia”, 2011.

Kluszczyński R.W., "Nomadic Images: Transmediality and Hybridity in Contemporary Media Art", Art Inquiry 2011, no. 15, p. 119-133.

Składanek M., "Transmedialność i postmedialność - dialektyka konwergencji i dywergencji w nowych mediach”, in: T. Załuski (ed.), Sztuki w przestrzeni transmedialnej, Łódź: Akademia Sztuk Pięknych im. Władysława Strzemińskiego w Łodzi, 2010.

Załuski T., “Transmedialność?”, in: idem (ed.), Sztuki w przestrzeni transmedialnej, Łódź: Akademia Sztuk Pięknych im. Władysława Strzemińskiego w Łodzi, 2010. 